\title{
Protected Areas in Brazil and Aichi Target 11: National Achievements
}

\author{
Nájila Rejanne Alencar Julião Cabral ${ }^{1}$, Adeildo Cabral Silva ${ }^{1, ~}{ }^{*}$, Regina Cleane Marrocos ${ }^{2}$ \\ ${ }^{1}$ Civil Engineering Department, Ceará Federal Institute, Ceará, Brazil \\ ${ }^{2}$ Ceará Federal Institute, Ceará, Brazil
}

Email address:

najila@ifce.edu.br (N. R. A. J. Cabral), cabral@ifce.edu.br (A. C. Silva), cleanemarrocos@gmail.com (R. C. Marrocos)

*Corresponding author

\section{To cite this article:}

Nájila Rejanne Alencar Julião Cabral, Adeildo Cabral Silva, Regina Cleane Marrocos. Protected Areas in Brazil and Aichi Target 11: National Achievements. International Journal of Environmental Monitoring and Analysis. Vol. 7, No. 6, 2019, pp. 112-117. doi: $10.11648 /$ j.ijema.20190706.11

Received: October 10, 2019; Accepted: November 9, 2019; Published: December 2, 2019

\begin{abstract}
Brazil is a signatory to the Convention on Biological Diversity (CBD). Therefore, it has commitments to safeguard part of its territory. Considering the achievement of Aichi Target 11, this article aims to show the results of quantitative research of protected areas in Brazil, a developing country, with emphasis on the state of Ceará. The paper highlights the quantity of Conservation Units, a type of Brazilian protected area. It describes two analyses. First, considering a secondary database, the study concentrated on the situation and progress of the Brazilian Conservation Units in achieving Target 11. Then, regarding to meet Target 11, it examined Conservation Units in the State of Ceará. Nowadays, Brazil has 2,309 Conservation Units, including Integral Protection Group and Sustainable Use Group. The results of this research indicate that Brazil has $18.60 \%$ of terrestrial protected area and $26.45 \%$ of marine protected area. Therefore, they are sufficient to meet Target 11. Data shows percentage above the target, even in 2018, two years before the deadline. The state of Ceará has 116 Conservation Units with $326.61 \mathrm{Km}^{2}$ of protected area. It is $21.92 \%$ of all Ceará's geographical extension which contributes for the empowerment of Brazilian commitments regarding the national plans and also the Convention on Biological Diversity, even though, it represents only $5 \%$ of total number of Brazilian Conservation Units.
\end{abstract}

Keywords: Aichi Target 11, Protected Area, Brazil, Conservation Unit, Convention on Biological Diversity

\section{Introduction}

Protected areas are an important global strategy for the protection of natural resources. They allow a condition of an ecosystem where the structure and function are unimpaired by human-caused stresses [1-3].

Brazil is a signatory to the Convention on Biological Diversity (CBD). Therefore, it has commitments to safeguard part of its territory. After Brazil ratified the CBD in 1998, it developed initiatives to protect biodiversity, including the National Biodiversity Action Plan. Although human pressure on ecosystems results in loss of biodiversity, human pressures are increasing in Latin American, African and Asian protected areas. For that reason, it is also very important to create and maintain protected areas, in developing countries, such as Brazil. There are different types of protected areas in Brazil that favor the conservation or preservation of natural resources. An act of the government in any of its fields (federal, state or municipal) can establish a protected area in Brazil. Protected areas include Permanent Preservation Areas (PPA), Legal Reserve Areas (LRA), environmental easement, Areas of Special Tourist Interest; Indigenous Reserves; Conservation Units, and others. Each protected area has a management objective and an important role in protecting environmental resources and economic development [4-7].

Human pressure inside protected areas is likely compromising national progress toward Convention on Biological Diversity obligations. Almost three-quarters of nations have $>50 \%$ of their protected land under intense human pressure [5]. Activities such as urban and agricultural expansion cause environmental impacts on and around protected areas. Advancing biodiversity studies to measure 
damage levels as well as predicting future impacts assists in implementing necessary measures to protect environmental resources $[8,9]$.

The tenth Meeting of the Conference of Parties (COP), in 2010, in Aichi, Japan, adopted Strategic Plan for Biodiversity, including the Aichi Biodiversity Targets [10].

Aichi Target 11 refers to protect, by 2020, at least 17 per cent of terrestrial and inland water areas and 10 per cent of coastal and marine areas. This target is related to Sustainable Development Goals and its specific indicator is the percentage of protected areas and their territorial extension. Some authors calls attention to the fact that developing countries are struggling to meet Aichi Target 11, by the poor coverage of protected marine areas or by difficulties of implementing measures to protect the environment [10-14].

This paper aims to report the findings of quantitative research of protected areas in Brazil, a developing country, with emphasis on the state of Ceará, considering the achievement of Aichi Target 11, from Strategic Plan for Biodiversity 2011-2020.

\section{Materials and Methods}

The research study area is the State of Ceará. It is located in the Northeast of Brazil. Figure 1 shows the location of Brazil and, specifically, of Ceará, in the Northeast. The geographical extension of Ceará is $148,825.6 \mathrm{~km}^{2}$ [15].

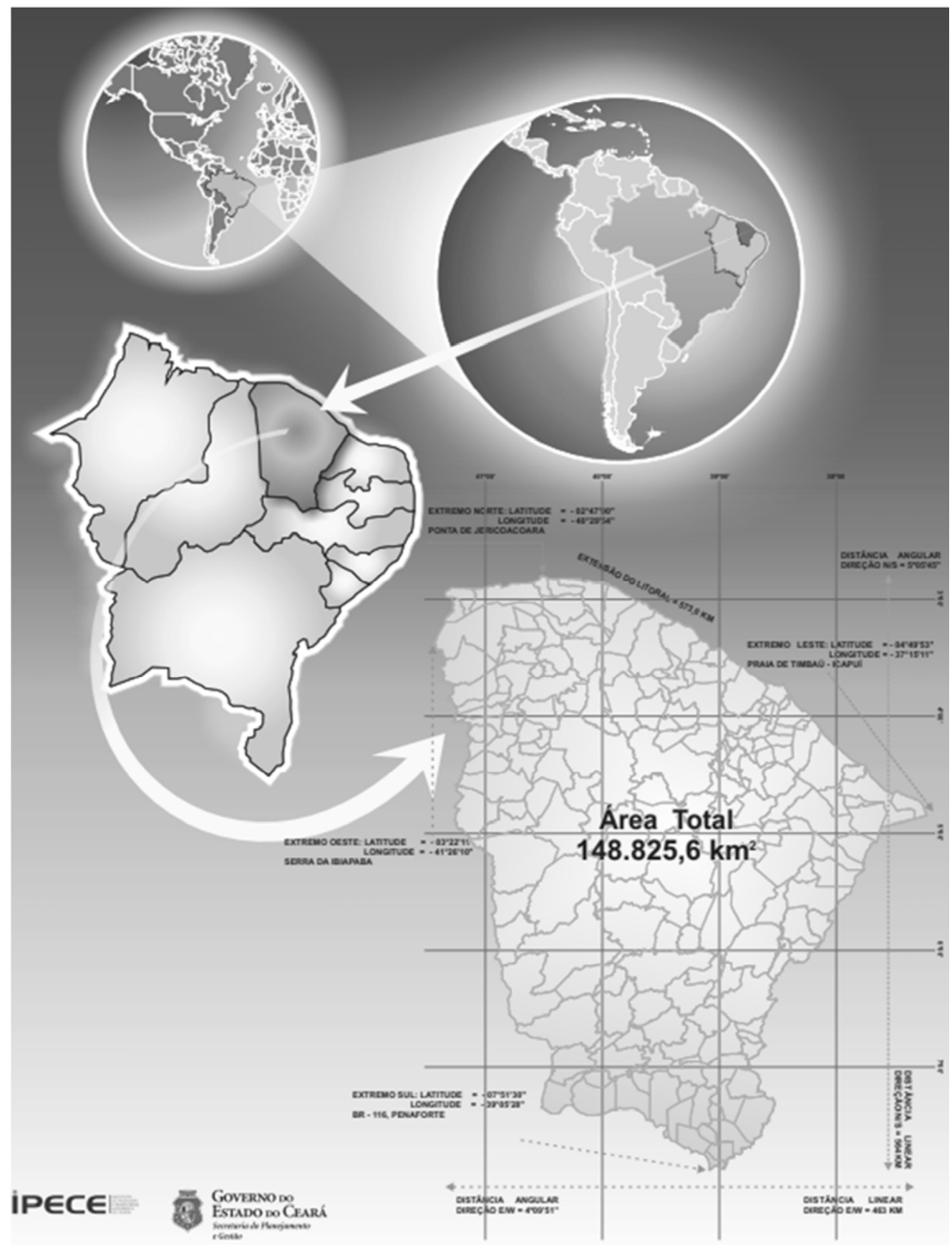

Figure 1. Location of Brazil and specifically Ceará, in the Northeast. 
The study used quantitative data from different sources, and public acts that created protected areas in Brazil and specifically in Ceará. This paper highlights the quantity of Conservation Units. Thus, Conservation Units were used and made this research unique. Although there are a Conservation Unit National Registry and a Conservation Unit State Registry in Ceará, all the units are not registered. Therefore, science references were used to map the data and carry out hierarchical analyses from Conservation Units $[6,7,16]$.

We used data from Conservation Unit National Registry, July 2019, as database for Brazilian Conservation Units. Between 1945 until December 2018, we collected the database, regarding the State of Ceará. Database began exactly in 1945, when Ceará created its very first protected area called Araripe National Forest [17].

Conservation Units are ruled by the Federal Law $n^{\circ} 9,985$, July 18, 2000; were separated in two clusters: Integral Protection and Sustainable Use. There are five types in Integral Protection Group: National Park, Biological Reserve, Ecological Station, Natural Monument and Wildlife Refuge. Regarding Sustainable Use Group there are seven types: Environmental Protection Area, Relevant Ecological Interest Area, National Forest, Extractive Reserve, Fauna Reserve, Sustainable Development Reserve and Natural Heritage Private Reserve [18].

In Ceará, until the year 2000, there was a possibility of creating specific protected area called Private Ecological Reserve. The Federal Decree $n^{\circ}$ 88,336, January 31, 1984 allowed the creation of this type of protected area. This paper considered Private Ecological Reserve (PER), created by the State Acts, as a Conservation Unit, for the State Laws approach that. Nowadays, this type (PER) cannot be created anymore, because the Laws were changed, and its creation became prohibited [19].

\section{Results}

The results involved two analyses. Firstly, the paper concentrated on the situation and progress in achieving
Target 11 from all Brazilian protected area, by a secondary database document. Secondly, it examined protected areas in Ceará, our study case, concerning the Integral Protection Group and Sustainable Use Group. The analyses focus on the achieving Target 11, from Strategic Plan for Biodiversity 2011-2020 [10].

\subsection{Brazilian Status and Aichi Biodiversity Target 11}

Brazil, nowadays, has 2,309 Conservation Units, in all types, including Integral Protection Group and Sustainable Use Group. We have 2,546,796.89 $\mathrm{km}^{2}$ protected of all national territory. Table 1 illustrates the general data from terrestrial and marine protected area, regarding Conservation Unit National Registry [16].

Table 1. Brazilian Conservation Units and their percent of terrestrial and inland water protected areas, 2019.

\begin{tabular}{llll}
\hline & $\begin{array}{l}\text { Inland protected } \\
\text { area }\end{array}$ & $\begin{array}{l}\text { Terrestrial } \\
\text { protected area }\end{array}$ & $\begin{array}{l}\text { Marine } \\
\text { protected area }\end{array}$ \\
\hline Area $(\mathrm{Km} 2)$ & $2,546,796.89$ & $1,583,508.28$ & $963,288.61$ \\
Percent $(\%)$ & & 18.60 & 26.45 \\
\hline
\end{tabular}

Source: The authors, based on [16].

The Target 11 refers to protect, by 2020 , at least 17 per cent of terrestrial and inland water areas, and 10 per cent of coastal and marine areas. The results of this research show that Brazil has $18.60 \%$ of terrestrial protected area and $26.45 \%$ of marine protected area (see Table 1) [10].

Although the relevance of quantitative issues of Brazilian Conservation Units has resulted above the Target 11 for both terrestrial and marine areas, we cannot see effectiveness of natural resources management inside them; so, we cannot say that all Conservation Units are really protecting environmental resources and biodiversity.

In 2019, there are 742 Conservation Units in Integral Protection Group and 1,567 in Sustainable Use Group. Table 2 illustrates data from each type of Conservation Units, quantitative and protected area extension.

Table 2. Brazilian Conservation Units Groups and their protected area percentage, 2019.

\begin{tabular}{llll}
\hline Types & Quantitative & protected area $\left(\mathbf{k m}^{\mathbf{2}}\right)$ & Percent $(\mathbf{\%})$ \\
\hline National Park & 455 & $363,545.12$ & \\
Biological Reserve & 64 & $56,207.99$ & $119,623.62$ \\
Ecological Station & 95 & $116,432.52$ & \\
Natural Monument & 56 & $6,367.17$ & 32.14 \\
Wildlife Refuge & 72 & $662,176.42$ & \\
Integral Protection Group & 742 & $1,296,318.80$ & \\
Environmental Protection Area & 346 & $1,144.60$ & \\
Relevant Ecological Interest Area & 51 & $314,014.88$ & \\
National Forest & 108 & $154,967.10$ & \\
Extractive Reserve & 95 & 0 & 67.86 \\
Fauna Reserve & 0 & $112,446.78$ \\
Sustainable Development Reserve & 39 & $5,728.32$ \\
Natural Heritage Private Reserve & 922 & $1,884,620.48$ & 100 \\
Sustainable Use Group & 1,567 & $2,546,796.89$ & \\
All types from both groups & 2,309 & & \\
\hline
\end{tabular}

Source: The authors, based on [16]. 
If we review, in the first place, some types of Conservation Units do not exist (see Table 2), but we have known that not all units are registered in Conservation Unit National Registry, as we inform before. Thus, it is possible to affirm that Brazil has much more protected area than 2,309. Even then, we could confirm that Brazil has achieved Aichi Target 11, considering the percentage indicated in Strategic Plan for Biodiversity 2011-2020 [10].

It is important to highlight that Brazil does not have any Fauna Reserve. According to Brazilian Law, Fauna Reserve is a natural area with native animal populations, terrestrial or aquatic, resident or migratory species, suitable for technical and scientific studies on the sustainable economic management of wildlife resources [18].

We can guarantee that all 2,309 Conservation Units were legally created, and that under the current Brazilian law, there is no way to reverse their creation. We can also guarantee that
Brazilian strategies were sufficiently geared towards environmental protection.

\subsection{Ceará Status and Aichi Biodiversity Target 11}

The results of the State of Ceará take a real situation of quantitative and protected area and their extension, for we have made a deep survey in all public acts (federal, state and municipal) until December 2018. The results show that the State of Ceará has 116 Conservation Units with $32,661 \mathrm{Km}^{2}$ of protected area. It is $21.92 \%$ of all Ceará's geographical extension. Table 3 illustrates data from each type of Conservation Unit, quantitative and protected area extension. In the results, we added a specific type, called Private Ecological Reserve (PER), in Sustainable Use Group, because this type was allowed until the year 2000 and, actually, The State Laws allow this approach.

Table 3. Conservation Units Groups of the State of Ceará and their protected area percentage, 2019.

\begin{tabular}{llll}
\hline Types & Quantitative & protected area $\left.\mathbf{( k m}^{\mathbf{2}}\right)$ & Percent $\mathbf{( \% )}$ \\
\hline National Park & 14 & 989,18 \\
Biological Reserve & 0 & 0 \\
Ecological Station & 3 & 253 \\
Natural Monument & 8 & 288,06 \\
Wildlife Refuge & 1 & 6 \\
Integral Protection Group & 26 & $1,536.24$ \\
Environmental Protection Area & 35 & $30,250.74$ \\
Relevant Ecological Interest Area & 7 & 7.52 \\
National Forest & 2 & 395.80 \\
Extractive Reserve & 2 & 304.08 \\
Fauna Reserve & 0 & 0 \\
Sustainable Development Reserve & 0 & 0 \\
Natural Heritage Private Reserve & 37 & 152.35 \\
Private Ecological Reserve & 7 & 15.94 \\
Sustainable Use Group & 90 & $31,125.69$ \\
All types from both groups & 116 & $32,661.93$ \\
\hline
\end{tabular}

Source: The authors

According to our data collection, three categories do not exist in Ceará scenario: Biological Reserve, Fauna Reserve and Sustainable Development Reserve, until the present date.

Only one of the Conservation Units (Table 3) are in seascape. It is called Pedra da Risca do Meio Marine State Park, with $33.2 \mathrm{~km}^{2}$ in marine area. About the Target 11, Ceará provides enough terrestrial protected area and complies Strategic Plan for Biodiversity 2011-2020 (see Table 3). Regarding marine protected area, Ceará does not comply the Aichi Target 11, but currently there are two governmental initiatives to create Marine Wildlife Refuges.

Under this basis, protected areas cover $21.9 \%$ of the State of Ceará. Therefore, we believe that it is important because we identify performance metrics to achieve Target 11 .

\section{Discussion}

Covering $18.60 \%$ of terrestrial area and $26.45 \%$ of marine area, Brazilian Conservation Units are sufficient to meet Target 11. This result introduces an important bias, for more recent data, collected by some authors are against to our finding, as shown in the results of their reports and articles [12-14].

Something is very interesting about Brazilian Conservation Units and their territorial extension (Table 2). The two types with the largest number of protected areas are the National Park and Natural Heritage Private Reserve categories. Both are areas where there are a strong restriction on land use and prohibited economic activities. The only permitted activities, in both categories, are environmental education, sustainable tourism and scientific research. If the territorial extension from both categories are summed, it makes $14.87 \%$ of the total. This result is very important, for in these areas human pressure is lower than, for example, in Environmental Protection Area category. This is the opposite of some authors, when it shows that human pressure is prevalent within many protected areas [5].

However, if we carefully study the territorial extension of the 346 Brazilian Environmental Protection Areas (EPA), we will find $50.89 \%$ of total. This category has intense human pressure, as it allows economic activities, as long as the area maintains environmental quality. This 
is the same that it was found by some authors in their study; it means the prevalence of human activities inside many protected areas $[5,20]$.

Although we get a Brazilian scenario in which land from some Conservation Units are under intense human pressure, they do contribute toward conservation targets, mainly Target 11. Environmental quality maintained, including some aspects of biodiversity, can persist in areas of high human pressure like what happens in Environmental Protection Area category. This occurs because we have many tools, which provide valuable conservation gains, for example, sustainable technical management. However, concerns may arise relating to whether it will be possible to record the effectiveness and the equitability in Brazilian Conservation Units because this research did not analyze their management.

Regarding our case study (Table 3), the State of Ceará, we note a similar trend to the Brazilian scenario, with the largest number of categories of National Parks and Private Natural Heritage Reserves. They represent only $3.49 \%$ of the total protected territory, while the 35 Environmental Protection Areas protect $92.61 \%$ of the total. As we reported, this category (EPA) offers opportunities for people who live there and perform many human activities. Other environmental tools (such as environmental licensing) control activities and their impacts on land and the environment. However, we cannot estimate the true level of protection in these areas, due to the lack of ways of measuring the human pressure as well as its effects on biodiversity.

Based on these previous analyses, this paper observed the commitment of both Brazil and the State of Ceará to achieve Target 11 .

\section{Conclusions}

This article documents how large is the commitment of Brazil to the Conservation Units coverage, in both terrestrial and marine areas, to achieve the Aichi Target 11. Data shows a percentage above the target, even in 2018 , two years before the deadline. Whereas some authors pointed to possible underestimated protected area coverage in developing countries due to the omission of financing and policies, this article points to real measurement of Brazilian protected areas $[12,14]$.

Although the State of Ceará represents only $5 \%$ of the total number of Brazilian Conservation Units, we understand that Ceará contributes to the empowerment of Brazilian commitments regarding the national plans and also to the Convention on Biological Diversity.

In synthesis in this paper we identified key issues such as (i) Brazilian scenario of environmental protection and Aichi Biodiversity Targets achievement, (ii) terrestrial and marine extension of protected areas for a better environmental strategies planning, (iii) difference between the quantitative of two groups of Brazilian Conservation Units to adapt to future Plan of Action according real need of management and (iv) quantitative framework of State of Ceará concerning terrestrial, inland water, coastal and marine protected areas. Thus, we illustrate some future possibilities in natural resources management in Conservation Units all over the country, including in State of Ceará.

\section{Acknowledgements}

We appreciate Technology and Environmental Management Postgraduate Programme (PGTGA) involvement with this publication, mainly PRPI/ARINTER 01/2018 internationalization programme.

\section{References}

[1] Dave, R., Saint-Laurent, C., Murray, L., Antunes Daldegan, G., Brouwer, R., de Mattos Scaramuzza, C. A., Raes, L., Simonit, S., Catapan, M., García Contreras, G., Ndoli, A., Karangwa, C., Perera, N., Hingorani, S. and Pearson, T. Second Bonn Challenge progress report. Application of the Barometer in 2018. IUCN: Gland, Switzerland, 2019; xii + 80pp.

[2] Worboys, G. L., W. L. Francis; M. Lockwood. Connectivity Conservation Management: a Global Guide. Earthscan: London, UK, 2010.

[3] Lausche, B. Integrated planning. Policy and law tools for biodiversity conservation and climate change. IUCN: Gland, Switzerland, 2019; xvi +120 pp. (https://doi.org?10.2305/IUCN.CH.2019.EPLP.88.en).

[4] Gray, C. L.; Hill, S. L. L.; Newbold, T.; Hudson, L. N.; Börger, L.; Contu, S.; Hoskins, A. J.; Ferrier, S.; Purvis, A.; Scharlemann, J. P. W. Local biodiversity is higher inside than outside terrestrial protected areas worldwide. Nature Commun. 2016. Vol. 7: 12306, $7 \mathrm{pp}$.

DOI: 10.1038/ncomms12306/www.nature.com/naturecommunications.

[5] Jones, K. R; Venter, O.; Fuller, R. A.; Allan, J. R.; Maxwell, S. L.; Negret, P. J.; Watson, J. E. M. One-third of global protected land is under intense human pressure. Science, 2018, pp. 360, 788-791.

[6] MMA - Ministério do Meio Ambiente. Estratégia e Plano de Ação Nacionais para a Biodiversidade. Brasília: Secretaria de Biodiversidade/Ministério do Meio Ambiente, 2017.

[7] Cabral, N. R. A. J. Resumo Executivo do relatório de Atividades do Grupo de Pesquisa Áreas Protegidas/CNPq/IFCE. Fortaleza: Laboratório de Energias Renováveis e Conforto Ambiental/Instituto Federal do Ceará, 2018.

[8] Mori, A. S.; Lertzman, K. P.; Gustafsson, L. Biodiversity and ecosystem services in forest ecosystems: a research agenda for applied forest ecology. Journal of Applied Ecology, 2017, v. 54, pp. 12-27.

[9] Naeem, S.; Chazdon, R.; Duffy, J. E.; Prager, C.; Worm, B. Biodiversity and human well-being: an essential link for sustainable development. Proc. R. Soc. B. London, 2016, v. 283, pp. 1-10.

[10] UNEP - United Nations Environment Programme. The Strategic Plan for Biodiversity 2011-2020 and the Aichi Biodiversity Targets. Nagoya: CDB, 2010. 
[11] UNEP - United Nations Environment Programme. Report of the Tenth Meeting of the Conference of the Parties to the Convention on Biological Diversity. Cancun: CDB, 2016.

[12] Smallhorn-West, P.; Govanc, H. Towards reducing misrepresentation of national achievements in marine protected area targets. Marine Policy, 2018, v. 97, pp 127-129.

[13] Amengual, J.; Alvarez-Berastegui, D. A critical evaluation of the Aichi Biodiversity Target 11 and the Mediterranean MPA network, two years ahead of its deadline. Biological Conservation, 2018, v. 225, pp. 187-196.

[14] Failler, P.; Touron-Gardic, G.; Traore, M-S. Is Aichi Target 11 Progress Correctly Measured for Developing Countries? Trends in Ecology \& Evolution, 2019, v. 34, n. 10, pp. 875879.

[15] IPECE - Instituto de Pesquisa Econômica do Ceará (2019). "Ceará em mapas" - Available on http://www2.ipece.ce.gov.br (acessed on 10 March 2019)
[16] MMA - Ministério do Meio Ambiente. Cadastro Nacional das Unidades de Conservação. Available on http://www.mma.gov.br/areas-protegidas/cadastro-nacionalde-ucs (acessed on 15 July 2019).

[17] Brasil. Decreto-Lei n. 9.226 de 2 de Maio de 1946. Dispõe sobre criação floresta nacional do Araripe-Apodi. Brasília: DOU, 4 maio1946.

[18] BRASIL. Lei $n^{\circ} 9.985$, de 18 de julho de 2000. Dispõe sobre o Sistema Nacional de Unidades de Conservação da Natureza e dá outras providências. Brasília: DOU. 19 jul. 2000.

[19] BRASIL. Decreto $n^{\circ} 89.336$, de 31 de janeiro de 1984. Dispõe sobre Reservas Econômicas e Áreas de Relevante Interesse Ecológico, e dá outras providencias. Brasília: DOU, 1 jan. 1984.

[20] W. F et al. Averting biodiversity collapse in tropical forest protected areas. Nature, 2012. V. pp. 489, 290-294. 